ISSN 0975-3311

UJBM, Vol. 8, No. 2, July - December 2009, pp 40.45

https://doi.org/10.12725/ujbm.15.4

\title{
COMPETENCIES OF COMMERCE TEACHER TRAINEES
}

\author{
Simon Philip* \& N.O. Nellaiyapen**
}



ABSTRACT

This is an attempt to investigate the teaching competencies of commerce teacher trainees. The main objectives of the study is find out whether there is any significant difference in the teaching competencies of commerce teacher trainees in respect of their gender, age, and medium studied. Sample of 200 B.Ed. trainees were selected by using purposive sampling technique. It is found that teacher trainees have low teaching competencies. It is revealed that there is significant difference in mean teaching competency scores of male and female, English and Malayalam medium teacher trainees. This study also revealed that there is no significant difference in mean teaching competency scores of trainees who are less than 22 years of age and above 22 years of the age group.

* Research Scholar, Department of Education, Annamalai University, Annamalai Nagar.

** Dept. of Adult and Continuing Education \& Extension Services, Annamalai University. 


\section{Introduction}

We are living in a complex and competitive world, where competency is the defining element. One of the goals of education is to equip the learners with adequate knowledge and skills. Excellence is often combined with competencies and academic proficiency. Competencies have become an inevitable element of teacher effectiveness. Therefore every teacher trainee during the training period should acquire a minimum level of competencies in teaching.

\section{Statement of the Problem}

The problem is entitled "Competencies of commerce teacher trainees."

\section{Objectives of the study}

1. To study competencies of teacher trainees

2. To study whether there is any significant difference between teacher trainees competencies with respect to
a. gender
b. age and
c. medium studied

\section{Hypotheses of the Study}

1. Teacher trainees have poor teaching competencies.

2. There is no significant difference between teaching competencies with respect to
a. gender
b. age and
c. medium studied 


\section{Method of Study}

Normative survey method is adopted in the present study. It seeks to obtain precise information concerning the current status of phenomena and to draw valid general conclusions from the facts discovered. This method of research attempts to describe and interpret what exist at present in the form of conditions, practices, process, trends, effects and attitude. In brief it is an attempt to analysis, interpret and repeat the present status of a social institution or the group. Thus in the present study, the investigators adopted normative survey method.

The sample for the present study is 200 commerce teacher trainees belonging to Kottayam and Ernakulam districts of Kerala State. The sample for the study had been selected by a purposive sampling technique.

The investigators used competency assessment scale constructed and validated by Simon Philip and Babu, R. (2007). This scale consists of 30 statements to measure the various aspects of competencies such as preinstruction, instruction, media application, skill management and evaluation. The scale is prepared on five point scale type with unsatisfactory, below average, average, above average and outstanding. Maximum score for this scale is 150 and minimum score is 30 . Hence having a score 75 or above is considered to have outstanding teaching competencies and a score of below 75 is considered to have poor teaching competencies. The reliability of the test is established by the investigators, which is found to be 0.76 by test re-test method. The item validity of statements are also established by selecting items which have ' $t$ ' values significant at 0.05 level or higher have been included in the scale. By applying necessary statistical techniques the analysis and interpretation of data are made.

\section{Results of the Study}

The following are the results of competencies of teacher trainees.

Table 1 : Mean and Standard Deviation scores of competencies of teacher trainees

\begin{tabular}{|l|c|c|c|}
\hline Variables & N & Mean & S.D \\
\hline Entire Sample & 200 & 49.44 & 7.26 \\
\hline
\end{tabular}


The arithmetic mean and Standard Deviation obtained for the competencies of commerce teacher trainees are 49.44 and 7.26 respectively. This shows that commerce teacher trainees have low teaching competencies.

Table 2 : The test of significance $\left({ }^{\prime} t\right.$ - test) of teacher trainees competencies in teaching

\begin{tabular}{|l|l|c|c|c|c|l|}
\hline Variables & Sub groups & N & Mean & S.D. & $\begin{array}{c}\text { 't' } \\
\text { Value }\end{array}$ & $\begin{array}{l}\text { Significance at } \\
0.05 \text { level }\end{array}$ \\
\hline Gender & Male & 75 & 47.60 & 4.88 & 3.19 & Significant \\
& Female & 125 & 50.55 & 8.20 & & \\
Age & Less than 22 Years & 148 & 48.89 & 5.98 & 1.80 & Not Significant \\
& Above 22 Years & 52 & 51.00 & 9.98 & & \\
Medium & English & 80 & 47.65 & 4.80 & 3.21 & Significant \\
Studied & Malayalam & 120 & 50.64 & 8.33 & & \\
\hline
\end{tabular}

It is found from the Table-2 that there is significant difference in mean teaching competency scores of

1. Male and female teacher trainees

2. English and Malayalam medium teacher trainees

Whereas there is no significant difference in mean teaching competency scores of

1. Trainees who are less than 22 years of age and above 22 years of age group

Female teacher trainees show better teaching competencies than male teacher trainees. Trainees who have studied in Malayalam medium schools have better teaching competencies than English medium students. Trainees who belong to the age group of above 22 years show better teaching competencies than trainees who belong to the age group of less than 22 years. Hence it is concluded that teacher trainees have poor teaching competencies. 


\section{Discussion}

This study revealed that teacher trainees have poor teaching competencies in Kerala state. There are various causes that prevent them from the acquisition of various skills. It could be due to lack of creativity of teachers and inefficient training. This study showed that female teacher trainees have better teaching competencies than male teacher trainees. Male teacher trainees should be encouraged, supported by teachers in the acquisition of various skills. But male teachers are often reluctant to apply new skills and methods. Therefore male teacher trainees should be promoted by the use of strategies and transfer it to new situations. Learning to apply new approaches takes time. It takes time to execute the strategies and it requires guidance and support from teachers. Only by practice the teacher trainees can learn to execute new skills faster and competently. It is also found that age is not a barrier in acquisition of skills.

\section{Suggestions and Recommendations}

- It is suggested that male teacher trainees should be given better attention in skill development and more skill development programmes should be undertaken.

- More applied aspects of non-cognitive strategies should be used to analyse the learner's cognitive processes and to conduct analytical tests and comprehension tests occasionally in their respective class rooms.

- It is recommended to conduct competitions in class rooms to stimulate the powers of non-cognitive processes in B.Ed. training colleges.

\section{Conclusion}

This study revealed that the teacher trainees have poor teaching competencies. Therefore it is important to focus our attention on laying emphasis on developing multiple competencies and able to apply and execute skill development strategies in teaching. It can be concluded that the teacher trainees who are resourceful agents of transformations of the young generation have to concentrate on accelerating teaching 
competencies. The parents and trainee teachers should model effective strategies in skill development and integral development of the teacher trainees.

\section{References}

1. Best, W. John. (2006). Research in Education, New Delhi: Prentice Hall of India Private Limited.

2. Bogdan, R., \& Biklen, S. (1982). Qualitative Research for Education. Boston: Allyn and Bacon. Bruner, J. (1990). Acts of meaning. Cambridge, MA: Harvard University Press.

3. Dacey, John and Travers, J. (1999). Human Development, New York: Fourth Edition Mc Graw Hill.

4. Duckworth, E. (1987). The Having of Wonderful ldeas and Other Essays on Teaching and Learning. New York: Teachers College Press.

5. Glasser, W. (1986). Control Theory in the Classroom. New York: Harper and Row.

6. Kellogg, R. T. (1994). The Psychology of Writing. New York: Oxford.

7. Ormond, J. E. (2000). Educational Psychology: Developing Learners. Upper Saddle River, NJ: Prentice-Hall, Inc.

8. Siegler, R. (1998). Children's Thinking. (3rd edition.) Upper Saddler River, NJ: PrenticeHall. 